
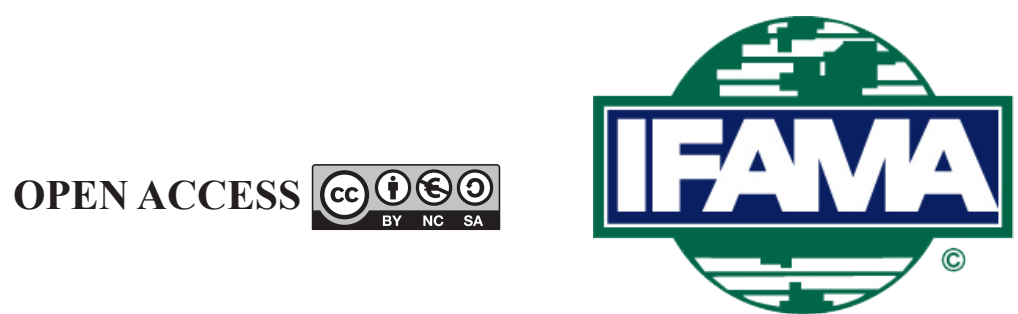

International Food and Agribusiness Management Review

Volume 24, Issue 1, 2021; DOI: 10.22434/IFAMR2020.0031

21 February 2020 / Accepted: 15 September 2020

\title{
Mantiqueira: innovating and disrupting in the egg business
}

\section{CASE STUDY}

\author{
Marcos Fava Neves ${ }^{\mathrm{a}}$, Allan Wayne Gray ${ }^{\mathrm{b}}$, Carlos Eduardo Lourenço ${ }^{\mathrm{c}}$ and Francisco Albert Scottt ${ }^{\oplus \mathrm{d}}$ \\ ${ }^{a}$ Professor, Planning and Strategy, EAESP/FGV and FEARP/USP, \\ Av. dos Bandeirantes, 3900, 14040-900 - Ribeirão Preto, SP, Brazil \\ ${ }^{b}$ Executive Director and Professor, Center for Food and Agricultural Business, \\ Purdue University, 403 W. State Street, West Lafayette, IN 47907-2058, USA \\ cProfessor, Business Administration, EAESP/FGV, Av. 9 de julho, 2029, 01313-902, São Paulo, SP, Brazil \\ ${ }^{d}$ Research Assistant and PhD Candidate, Agricultural Economics, \\ Purdue University, 403 W. State Street, West Lafayette, IN 47907-2058, USA
}

\begin{abstract}
Consumers' shifting tastes have made sustainable growth for firms in the food industry increasingly difficult. Scholars and industry practitioners constantly try to develop business strategies to deal with disruptions in modern food markets. This case uses Brazilian company Mantiqueira as an example of how a company can adopt demand-driven innovation and embrace disruption to aid its sustainable growth over the years. We follow the success of Mantiqueira in the market of eggs, from its humble beginnings until its dominance in the Brazilian market. With the use of data, the case (1) shows the current challenges faced by Mantiqueira and (2) asks readers to participate in the next round of decisions that Mantiqueira will have to make in order to hold its market share. This case is intended for use with graduate students and professionals in the agribusiness and food industries. It can be used to develop competencies associated with decision making for agribusiness firms, particularly for those faced with changes in the demand side that require new marketing strategies and capital investments.
\end{abstract}

Keywords: egg production, marketing, business strategy, product development, cage-free production JEL code: Q1, Q13

${ }^{\oplus}$ Corresponding author: scottf@purdue.edu

A teaching note has been prepared for this case study. Interested instructors at educational institutions may request the teaching note by contacting the author or IFAMA. 


\section{Introduction}

It is late afternoon when Leandro Pinto, the CEO of Mantiqueira, arrives for his interview at the charming restaurant located in Fundação Getúlio Vargas, in São Paulo, Brazil. Looking through the window, he observes a tropical thunderstorm approaching - a very common weather event during the early months of the year in a prone-to-flood São Paulo. 'I feel like I am in the middle of a bridge that connects two islands... I can either return to the island where I was, or I can move forward to the island where I have never been... It is the same feeling that I had in 1997,' Mr. Pinto commented in a reflexive manner.

Mr. Pinto is at a crossroads. On one hand, he can keep the successful business model that led his company to become the largest egg company in the Brazilian market, scale his operations, and invest even more in efficiency - a comfortable strategy in the short run. On the other hand, Mr. Pinto can focus on a new cycle of diversification and expansion for his company by investing in cage-free layer flocks, introducing plantbased products and ready-to-eat meals, and effectively launching his company into the uncertain.

More relaxed after dinner, Mr. Pinto started to tell the history of Mantiqueira Group.

\section{The history of Mantiqueira}

'Every entrepreneur must have gratitude; ingratitude is the biggest sign of a lack of character that someone can show. (Leandro Pinto)'

The history of Mantiqueira is closely related to its own founder, Leandro Pinto. Mr. Pinto is a charismatic and innovative leader who believes hard work is an indispensable part of one's personal development. His history shows exactly how important work is for him.

Mr. Pinto started to work early - at 12 years old - against the will of his parents, who preferred the formal education path. At the age of 15, in the city of São José dos Campos, he was already employed at a bank as an office boy. Before turning 18, Mr. Pinto returned to Itanhandu in the Brazilian state of Minas Gerais, where he was born, to begin his career as an entrepreneur. Using the spare capacity of his father's agriculture machinery company, he started producing and selling horse carts.

By 1986, he abandoned the cart business to become a representative of a machinery company. The venture, which had been very successful in its initial years, failed in 1987 amid the hyperinflation crisis in Brazil. Looking back, Mr. Pinto believes that failing was the best thing that could have happened to him. It taught him not only that businesses are cyclical and complex, but also that these cycles can bring new opportunities.

At the time Mr. Pinto filed for bankruptcy in 1987, his friend Mr. Juarez had a business proposal to share with him. Mr. Juarez, who had recently suffered a heart attack, felt he could not manage his egg farm with 30,000 hens anymore. He wanted Mr. Pinto to take over. A bankrupted Mr. Pinto saw the poultry farm as an opportunity to alleviate his financial situation. The only caveat was that he had no money to buy the business from Mr. Juarez.

That is when creativity struck. Mr. Pinto offered his car and a small leased truck to Mr. Juarez in exchange for renting the poultry farm. The deal allowed Mr. Pinto to change focus once again with the hopes of improving his financial situation. At the time, he thought, 'Chickens produce eggs every day. I will have a daily cash flow to honor my debts.'

It was not that simple. Mr. Pinto soon realized that the profit margin in the egg farm was not very big. In addition to being indebted and with no access to the credit market, he was also having problems in his personal life. Rogéria, his fiancée, broke up with him after discovering Mr. Pinto's true financial situation, which he had withheld from her. It was the closest he ever felt to abandoning the business life. But even 
though the marriage was off, Rogéria decided she would support him until he could get back on his feet. With her support, Mr. Pinto recalls gathering strength to honor his debts.

During the years of financial struggle, Mr. Pinto's new company, Mantiqueira, had no feed inventory, and Mr. Pinto remembers laying down at night and thinking about what the hens would eat the next day. He recalls that he always managed to feed them, but the process was not stress free. He remembers a time when he inadvertently bought contaminated corn from his neighbor to feed the flock, only to discover later that they stopped laying eggs. With no eggs, there would be no debt payment, and he would have to sell the 30,000 chickens. As a last resort, he bought corn from other producers in hopes that the chickens would get better. It took three days until the hens would lay eggs again.

He speaks with sadness about the only time in 31 years in business that he could not pay his employees. 'Every entrepreneur must have gratitude; ingratitude is the biggest sign of lack of character that someone can show,' he says. Mr. Pinto would not be ungrateful to his employees. He informed them about the situation and allowed them to buy groceries and medicine under his personal credit. 'Truthfulness generates confidence!' according to Mr. Pinto. To liquidate the rest of his debt, he gave the last pieces of his jewelry to his creditors. The painful process of financial recovery was over. He married Rogéria in 1989 - the same year in which he was, once again, debt-free.

In 1990, he built his own egg farm with 70,000 laying hens. In 1994, he built a second one with another 30,000 laying hens. Amid a market of ups and downs, and with a production capacity of 100,000 birds, Mr. Pinto decided it was time for expansion, so he returned to Mr. Juarez's farm to begin prospecting new clients.

\subsection{The expansion phase}

Mr. Pinto began prospecting in the Rio de Janeiro market. He promptly received an order from the Supermercado Paes Mendonça, a big supermarket chain. It would be a major step toward expanding production, but rumors about the financial health of the supermarket chain worried Mr. Pinto.

In his straightforward manner, he decided to meet with the supermarket's director of procurement, Mr. Agnaldo. Mr. Pinto was direct and sincere. He remembers telling Mr. Agnaldo that he could absorb the hit from delayed payments for one egg shipment, but he could not survive an entire month without payment, emphasizing his worries about the financial health of the supermarket. Mr. Agnaldo's answer was reassuring: 'Get me one truckload of your best quality product per day, on time, and we will pay every single day on time.' It was the commitment Mr. Pinto needed to expand production.

In 1996, he started to question the Brazilian way of producing eggs, which he perceived as archaic and too labor-intensive. He began researching new ways of producing eggs in Europe and frequently visited agribusiness fairs and other poultry farms. He realized that automated production was the future of the sector. At the time, Mr. Pinto's plans were to expand production by investing in ten extra barns, each holding 30,000 hens under a more labor-intensive production system. However, after investigating new technologies, he realized he could only invest in one barn of 50,000 hens under a more capital-intensive technology.

To scale up his activities, Mr. Pinto would have to negotiate. He contacted a Spanish supplier who wanted to enter the Brazilian market and offered to buy one automated barn from him, cash up front, as long as the supplier would allow Mr. Pinto to finance a second one. The supplier agreed, and by 1997, Mantiqueira became the first fully automated egg farm in Brazil. Birds were fed, and manure and eggs were collected with no human contact.

Since he was already familiar with Rio de Janeiro, Mr. Pinto decided to start increasing his market penetration there. At the time, retail in Rio de Janeiro was dominated by families of Portuguese origin. He approached Carlos Cunha, a young businessman of Portuguese descent who owned Supermarket Dallas. Mr. Cunha was 
known as a revolutionary at the time. Taking advantage of higher family incomes arising from the monetary stability of Brazil in the mid-1990s, he successfully developed a network of neighborhood markets in Rio de Janeiro instead of investing in larger stores.

After being invited to visit Mantiqueira's automated barns, Mr. Cunha informed Mr. Pinto that Mantiqueira would be the only egg supplier of Supermarket Dallas. Mr. Pinto recalls teasing Mr. Cunha: 'I do not know who is more irresponsible: you, for making me your only supplier, or me, for accepting it.'

Following Mr. Cunha's vetting of Mr. Pinto's operations, Mantiqueira was able to expand distribution to several retail stores in Rio de Janeiro. The impressive growth rate of the supermarket chains linked to Mr. Cunha's family - supermarkets Dallas, Rainha, and Continente - drew the attention of other big players in the retail industry. In 1999, the French-owned hypermarket Carrefour bought all three chains linked to Mr. Cunha's family. By that time, Mr. Pinto - already a friend of Mr. Cunha - made him a business proposition: 'Carlos, you are rich, young, and now you are unemployed. Do you want to become my business partner?'

Signed on a piece of napkin, which is preserved and stored, a successful business association was born that day. In fact, the partners determined the Mantiqueira valuation with the current revenue and a guess of future profits. There was no calculation of net discounted present value of future cash flow, no beta assessment, no weighted average cost of capital, nor any detailed valuation of the business. Mr. Pinto believes that the personal values of the two partners formed the foundation for what would become a fruitful partnership.

'We are a family. I was always a hard worker, always worked with gratitude and honesty. You cannot reap success if you do not sow the soil with hard work (Leandro Pinto).'

Mr. Cunha's extensive network, as well as his expertise of what retailers look for in an egg supplier, allowed Mantiqueira to develop close ties with their clients. The partnership also enabled Mr. Pinto to focus more on the egg-production process and research ways in which Mantiqueira could incorporate new technologies into its operations. This division of labor helped define what Mantiqueira is today: an innovative firm that focuses on product quality and excellent one-to-one client relationships.

During the expansion phase, Mantiqueira acquired the traditional Brazilian poultry farm Granja Santa Clara in 2002 and also started to acquire nearby farms to supply their poultry farms. That same year, they remodeled Mantiqueira's headquarters in Itanhandu and established a greenbelt surrounding the headquarters. Today, the area is considered a nationally protected environmental zone, as seen in Figure 1.

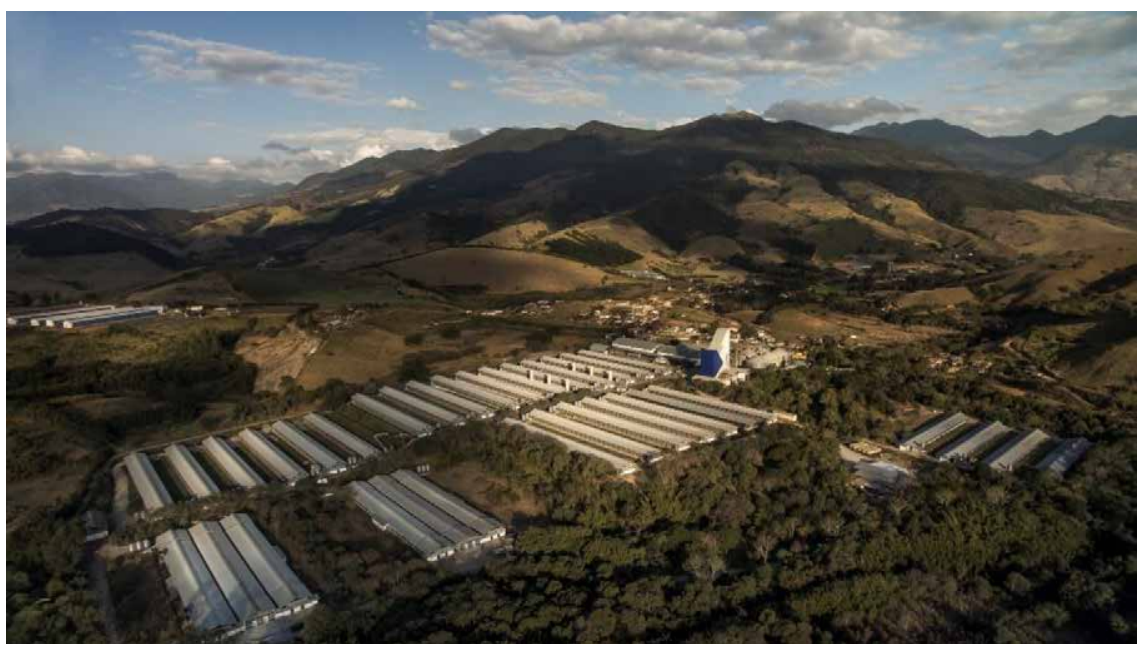

Figure 1. Mantiqueira, Itanhandu, Brazil. 
In 2004, the company began composting chicken manure at Horizonte Farm and using it to produce natural fertilizer. The product has been well received by the local agricultural community.

By the end of the 2000s, Mr. Pinto had an idea while visiting local corn and soybean farms in the state of Mato Grosso: he would start an egg farm there. Most of Mr. Pinto's colleagues were against the project because Mato Grosso is far from the major markets of Mantiqueira. But Mr. Pinto demonstrated how operations in the city of Primavera do Leste in Mato Grosso made strategic sense. The largest required inputs in egg production - corn and soybean meal - are produced abundantly there. Since eggs have more aggregated value than corn and soybean meal, the relative reduction in transportation costs to the consumers' markets made economic sense.

In 2008, Mantiqueira officially opened the largest egg farm in the world, with a capacity of 6 million laying hens, in Primavera do Leste (Figure 2). It was one of the biggest inflection points in the trajectory of innovation by Mantiqueira. Not long after that, the company decided to incorporate feedlot cattle and soybean and corn production, officially becoming a group of companies.

\section{Mantiqueira's integrated companies}

The personal values that guide Mr. Pinto and Mr. Cunha are the DNA of Mantiqueira. They are reflected in the mission, vision, and values of the company, as stated in Figure 3.

Today, Mantiqueira is an agricultural conglomerate that encompasses poultry and cattle activities, storage and grain production, and fertilizer production, as seen in Figure 4.

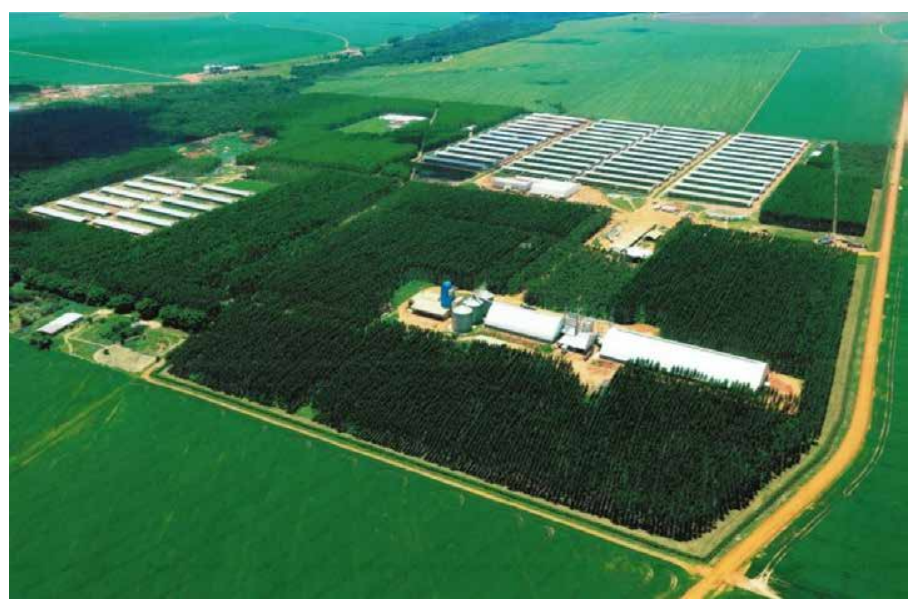

Figure 2. Mantiqueira egg farm, Primavera do Leste, Brazil.

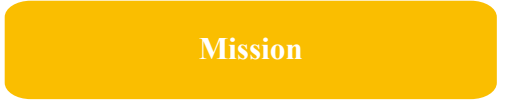

To provide healthy food to consumers in a sustainable way, always respecting communities and the environment to generate value for our clients, partners, collaborators, and shareholders

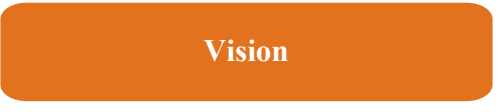

To be the most admired agribusiness company in Brazil

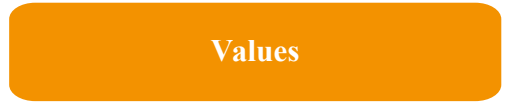

Simplicity; Integrity; Respect; Security; Care

Figure 3. Mantiqueira's mission, vision, and values (Mantiqueira, 2019). 


\section{Mantiqueira Group}

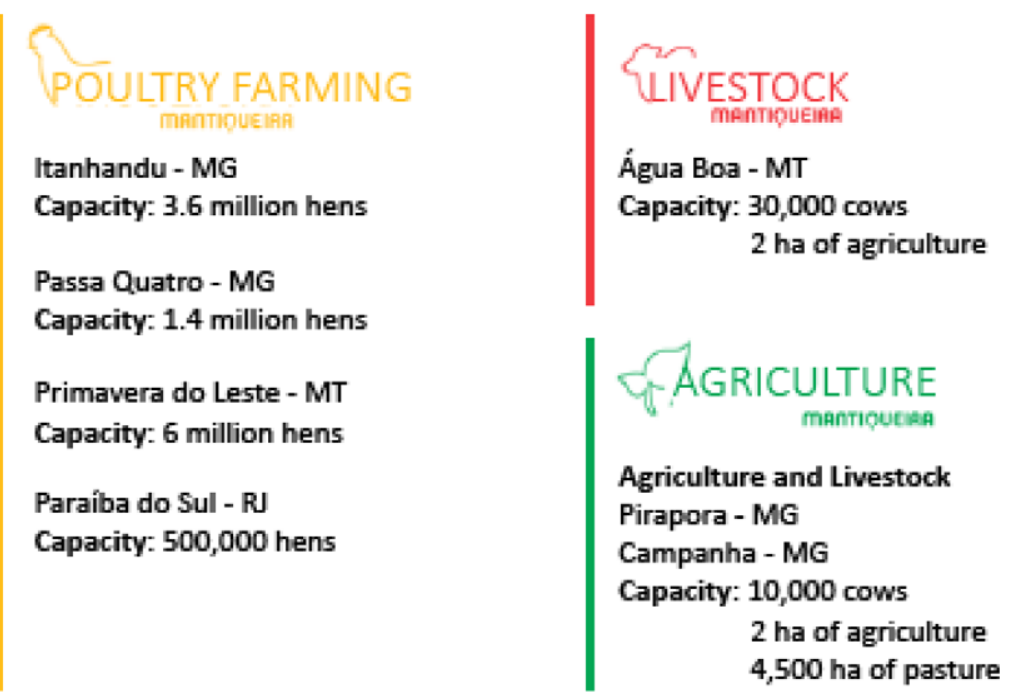

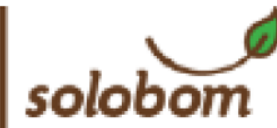

Fertilizer (by composting)

Capacity: 800 tons/day

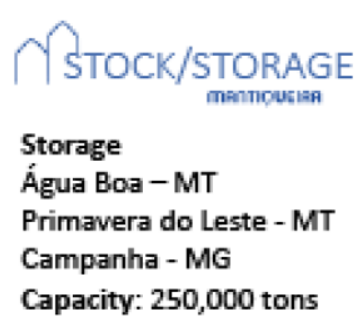

Figure 4. Operations of Mantiqueira.

The company has 2,100 employees. Poultry represents $75 \%$ of Mantiqueira's activities and most of its labor force.

All the steps of production are mechanized, including production of feed (with specific diets for each phase of bird's development), barn management (including the feeding process itself and manure and egg collection), and classification and packaging of eggs (separated by size, quality, and type of product). The mechanized and automated system used by Mantiqueira guarantees higher quality eggs in comparison to the average quality of eggs in the market. Automation also allows the final consumer to be the first human being to have contact with the eggs.

Mantiqueira divides production between four sites: the large Primavera do Leste unit, two barns in Minas Gerais (the Granja Santa Clara unit in the city of Passa Quatro and Granja Mantiqueira in Itanhandu), and one site in the city of Paraíba do Sul in the state of Rio de Janeiro. The latter, which only opened recently, has 500,000 laying hens and is the first large-scale operation of cage-free eggs in Brazil.

The eggs from Mantiqueira are sold in every state of Brazil, but the largest market shares are in the states of Rio de Janeiro, São Paulo, and Minas Gerais.

\subsection{Product lines}

Besides traditional eggs, Mantiqueira has the following special lines of eggs and egg-based products:

- The 'Mantiqueira Organic Brown Eggs' are produced following the Brazilian organic production and animal welfare guidelines. Hens are cage free and allowed pasture area; feed contains only organic certified grains. Mantiqueira organic eggs are certified with the IBD organic seal. They are also certified by the seal Certified Humane Brasil, a branch of Certified Humane, one of the leaders in animal welfare certification in the world. Certified Humane seals follow the international standards known as Certified Humane Raised \& Handled.

- The 'Mantiqueira Happy Eggs ${ }^{\circledR}$ ' are produced by cage-free chickens and comply with international animal welfare standards from Certified Humane Raised \& Handled by Certified Humane Brasil.

- The 'Mantiqueira Omega 3 Eggs' are rich in selenium and vitamin E. They are intended to support the immune system, regulate blood pressure, improve skin health, and supply antioxidants. Consumers concerned about health and nutrition may benefit from this product. 
- The 'Mantiqueira From the Farm Eggs' are produced by cage-free hens and are aimed to have a highly intense egg yolk color. They are also certified with Certified Humane Brasil seal following the international standards of Certified Humane Raised \& Handled.

- The 'Mantiqueira Gourmet Eggs ${ }^{\circledR}$ ' have a bright egg yolk color. The company targets consumers interested in artisanal cooking who may use the product as the main ingredient of a lively and colorful dish.

- The 'Mantiqueira Galinha Pintadinha Eggs' use a popular Brazilian cartoon to incentivize egg consumption by younger generations.

- Mantiqueira has introduced liquid egg-based products known as 'Eggscellent', which includes eggwhite, egg-yolk, and other liquid egg products.

- The 'Mantiqueira Quail Eggs' are used in salads and snacks.

- The 'Mantiqueira Solidarity Eggs' designates $10 \%$ of its revenue to institutions that contribute to social causes. Since 2016, these specialized product lines have benefited many NGOs and nonprofits linked to social improvement in women and children's health, education, and athletics.

More information about Mantiqueira's product line can be found in Figure S1 in the supplementary material. Other promotional products can be found in the Appendix.

\section{Egg business: world and Brazilian markets}

The beginning of egg production can be traced to thousands of years ago, when chickens were domesticated. In small-scale egg production, eggs do not require complex handling. Hens are raised free-range, and their feed is provided from a pasture or the farmer. Large-scale egg production requires more care. Diets must be optimized, sanitary requirements must be met, and eggs must be classified by size and quality, according to consumer demand.

Large-scale egg production consists of six main steps: (1) acquisition of chicks (one day old); (2) raising of chickens; (3) egg production; (4) feeding, manure removal, and egg collection; (5) classification of eggs; and (6) transportation of eggs. The entire production cycle takes up to 90 weeks, as seen in Figure 5.

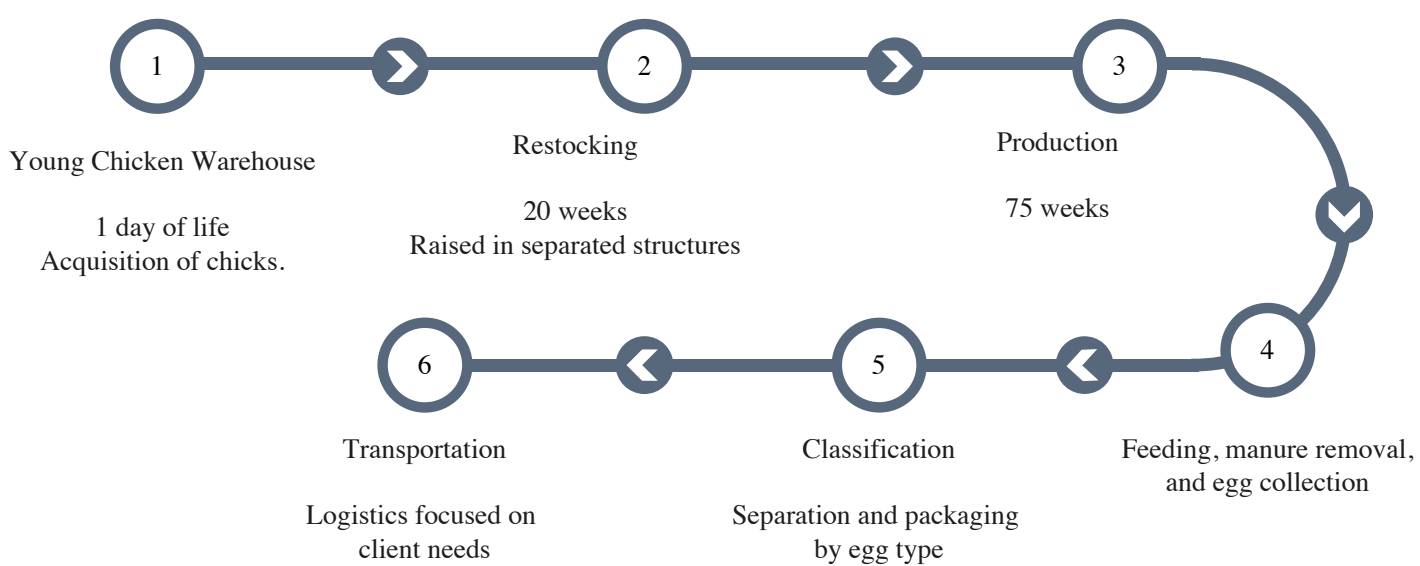

Figure 5. Cycle of egg production (Mantiqueira internal materials). 


\subsection{World market}

Egg production mainly supplies local and national markets and are rarely exported to other countries. Eggs are perishable and fragile, so there is a high risk for waste during transportation, and these risks increase with distance. The high transportation cost per egg can further reduce the already small profit margin, so transportation and logistics are important elements in egg production.

Table 1 shows egg production for the selected countries. Countries with high populations - including China, USA, India, Mexico, Japan, and Brazil - tend to have higher total egg production (Moura et al., 2019).

Brazil ranked as the seventh highest egg-producing country in the world in 2016. From 2007 to 2016, the country saw a $28.7 \%$ increase in production, reaching 2.3 million tons of eggs. Despite the growth in production, Brazilian per capita consumption is relatively low compared to other countries, as shown in Table 2.

Table 2 shows that China, Mexico, and Japan are the largest per capita egg consumers in the world, consuming more than 300 eggs per capita/year. According to Moura et al. (2019), in 2017, Brazil consumed 192 eggs per capita/year, an increase of $47 \%$ over the 131 eggs per capita/year of 2007 . The pro-consumption campaigns, under the coordination of 'Instituto Ovos Brasil'", and the strengthening of the internal market during the time were responsible for the increase (OvoSite, 2019).

\subsection{United States egg market}

The United States egg market provides a good benchmark for the Brazilian egg market. Both countries have a dynamic and diversified agricultural sector capable of responding to demand shocks, large population, and vast territory. Also, Brazilian consumption patterns are influenced by the United States. As such, Mantiquiera pays close attention to the United States market to help anticipate potential changes in the Brazilian market. According to the United States Department of Agriculture National Agricultural Statistics Service (USDANASS), the country produced approximately 106.5 billion egg units in 2018 . During that year, $60 \%$ of shell eggs were destined for retail; less than 3\%, to exports; and the remaining, as inputs for other products (United Egg Producers, 2019).

Table 1. Egg production in the world, 2007 to 2016 (in thousand tons) (Moura et al., 2019). ${ }^{1}$

\begin{tabular}{llllllllllr}
\hline & China & USA & India & Mexico & Japan & Russia & Brazil & Indonesia & Ukraine & Turkey \\
\hline 2007 & $21,833.1$ & $5,395.00$ & $2,947.0$ & $2,290.8$ & $2,583.2$ & $2,121.7$ & $1,779.1$ & $1,174.6$ & 807.2 & 795.3 \\
2008 & $23,292.2$ & $5,344.0$ & $3,047.0$ & $2,337.2$ & $2,553.5$ & $2,118.5$ & $1,844.6$ & $1,122.6$ & 855.2 & 824.4 \\
2009 & $23,633.5$ & $5,374.0$ & $3,230.0$ & $2,360.3$ & $2,507.5$ & $2,194.5$ & $1,921.8$ & $1,071.5$ & 883.8 & 864.5 \\
2010 & $23,820.0$ & $5,437.0$ & $3,378.1$ & $2,381.3$ & $2,515.3$ & $2,260.6$ & $1,948.0$ & $1,121.1$ & 973.9 & 740.0 \\
2011 & $24,231.6$ & $5,475.0$ & $3,466.3$ & $2,458.7$ & $2,482.6$ & $2,283.6$ & $2,036.5$ & $1,027.8$ & $1,064.0$ & 809.6 \\
2012 & $24,659.1$ & $5,589.0$ & $3,655.0$ & $2,318.2$ & $2,506.7$ & $2,333.6$ & $2,083.8$ & $1,139.9$ & $1,092.6$ & 931.9 \\
2013 & $24,786.9$ & $5,778.0$ & $3,835.2$ & $2,516.0$ & $2,521.9$ & $2,283.6$ & $2,171.5$ & $1,223.7$ & $1,121.4$ & $1,031.0$ \\
2014 & $24,942.6$ & $5,974.0$ & $4,111.3$ & $2,567.2$ & $2,501.9$ & $2,313.5$ & $2,240.5$ & $1,244.3$ & $1,119.8$ & $1,071.5$ \\
2015 & $25,842.1$ & $5,756.8$ & $4,316.6$ & $2,652.5$ & $2,520.8$ & $2,357.2$ & $2,260.9$ & $1,372.8$ & 959.5 & $1,045.4$ \\
2016 & $26,835.4$ & $6,037.5$ & $4,561.0$ & $2,720.1$ & $2,562.2$ & $2,412.8$ & $2,289.4$ & $1,428.1$ & 854.6 & $1,122.0$ \\
Var. (\%) & 22.9 & 11.9 & 54.8 & 18.7 & -0.8 & 13.7 & 28.7 & 21.6 & 5.9 & 41.1 \\
Average & $24,387.7$ & $5,616.0$ & $3,654.7$ & $2,460.2$ & $2,525.6$ & $2,267.9$ & $2,057.6$ & $1,192.6$ & 973.2 & 923.5 \\
\hline
\end{tabular}

${ }^{1}$ Values were rounded to one decimal place.

\footnotetext{
${ }^{1}$ Instituto Ovo Brasil is Brazilian egg institute for the promotion of egg and egg products. More information available at: http:// www.ovosbrasil.com.br/site/
} 
Table 2. Annual per capita consumption of eggs (units), 2007 to 2017 (Moura et al., 2019). ${ }^{1}$

\begin{tabular}{|c|c|c|c|c|c|c|c|c|c|c|c|}
\hline & 2007 & 2008 & 2009 & 2010 & 2011 & 2012 & 2013 & 2014 & 2015 & 2016 & 2017 \\
\hline China & 316 & - & 320 & - & 336 & - & - & - & 300 & 310 & - \\
\hline USA & 250 & 247 & 246 & 249 & 234 & 255 & 259 & 263 & 261 & 252 & 274 \\
\hline Mexico & 329 & 331 & 355 & 365 & 358 & 335 & 347 & 398 & 352 & - & - \\
\hline India & $35^{*}$ & $36^{*}$ & $38^{*}$ & $39^{*}$ & $40^{*}$ & - & - & 62 & 63 & - & - \\
\hline Japan & $327^{*}$ & $323^{*}$ & $316^{*}$ & $316^{*}$ & $315^{*}$ & - & - & - & 329 & 347 & - \\
\hline Russia & $238^{*}$ & $236^{*}$ & $243^{*}$ & $250^{*}$ & $253^{*}$ & 269 & 269 & 269 & 285 & 273 & - \\
\hline Brazil & 131 & 120 & 120 & 149 & 163 & 162 & 169 & 182 & 191 & 190 & 192 \\
\hline Indonesia & 93 & $85^{*}$ & $76^{*}$ & $78^{*}$ & $70^{*}$ & - & - & - & 63 & - & - \\
\hline Ukraine & 262 & 269 & 283 & 282 & 327 & $211^{*}$ & $244^{*}$ & - & - & - & - \\
\hline Turkey & 165 & $159^{*}$ & $156^{*}$ & $158^{*}$ & 168 & - & - & $119^{*}$ & 194 & - & - \\
\hline South Africa & $108^{*}$ & $112^{*}$ & $122^{*}$ & $112^{*}$ & $122^{*}$ & 163 & 148 & 142 & 142 & 141 & 128 \\
\hline Argentina & $178^{*}$ & $173^{*}$ & $180^{*}$ & $197^{*}$ & 243 & - & - & - & 256 & 273 & - \\
\hline Canada & $188^{*}$ & $183^{*}$ & $183^{*}$ & $194^{*}$ & $206^{*}$ & $214^{*}$ & $223^{*}$ & $223^{*}$ & 182 & 239 & - \\
\hline Australia & $95^{*}$ & $105^{*}$ & $120^{*}$ & $105^{*}$ & 216 & - & - & - & 214 & 235 & - \\
\hline France & $245^{*}$ & $248^{*}$ & $238^{*}$ & $232^{*}$ & 222 & $207^{*}$ & $243^{*}$ & $243^{*}$ & 216 & - & - \\
\hline Italy & $193^{*}$ & $197^{*}$ & $212^{*}$ & $212^{*}$ & 206 & - & - & $229^{*}$ & 216 & - & - \\
\hline Sweden & $187^{*}$ & $183^{*}$ & $192^{*}$ & $200^{*}$ & 207 & - & - & - & 217 & $195^{*}$ & - \\
\hline Germany & 209 & 208 & 209 & 214 & 217 & 220 & 224 & 232 & 231 & 235 & - \\
\hline
\end{tabular}

1 *Transformed in units by dividing ton by the average egg weight.

Per capita consumption has increased in recent years. In 2010, per capita egg consumption in the United States was 249; by 2017, it had risen to 274 (American Egg Board, 2019; United Egg Producers, 2019). At the same time, the United States observed an increase in the number of layers. In 2017, the United States had 319 million layers, laying an average of 289 eggs/day (United Egg Producers, 2019).

Two trends are evident in the United States market: fewer producers supplying eggs and the increase of organic and cage-free eggs. First, the 10 largest United States egg-producing companies own 53\% of the layers, and the top 55 producers account for approximately $98 \%$ of all layers (WATTAgNet, 2019). Secondly, more than $18 \%$ of the layer flock produced table eggs under cage-free or organic systems in the United States in 2018. Cal-Maine Inc, the largest company in the sector, reported that $32 \%$ of its revenue comes from the market of more differentiated eggs (e.g. specialty, cage-free, and organic eggs), which represents $23.5 \%$ of its total production (Cal-Maine Foods, Inc, 2018).

\subsection{Brazilian egg market}

According to the Brazilian Institute of Geography and Statistics (IBGE), egg production in 2018 was 43.2 billion eggs, or 120 million boxes of 30 dozen. Brazilian production is generally spread across the nation, but clusters of production exist in the states of Espírito Santo, São Paulo, and Minas Gerais in the southeastern part of Brazil and in Pernambuco in the Northeast. Top 3 states are responsible for almost $55 \%$ of egg production, as indicated by Figure 6 (IBGE, 2019).

The share of eggs in the Brazilian diet has increased in the last decades, as indicated by Supplementary Figure S2, and nutritionists have started recommending eggs as an affordable high-protein, low-calorie product. This was not always the case. During the 2000s, the benefits of eggs were in the center of the debate about health concerns. Egg consumption was associated with high cholesterol outcomes in humans, a vision that changed after a push to correct the overestimation of cholesterol content in eggs (Saviani, 2019). 
Table 3. Top United States egg producers, 2019 (WATTAgNet, 2019).

\begin{tabular}{lll}
\hline Ranking & Company & Hens (millions) \\
\hline 1 & Cal-Maine Foods & 40.25 \\
2 & Rose Acre Farms & 26.60 \\
3 & Versova Holdings LLC & 21.10 \\
4 & Hillandale Farms & 20.00 \\
5 & Daybreak Foods & 14.00 \\
6 & Michael Foods & 13.29 \\
7 & Rembrandt Enterprises & 12.50 \\
8 & Center Fresh Group & 10.50 \\
9 & Midwest Poultry Services LP & 9.80 \\
10 & Prairie Star Farms & 9.40 \\
\hline
\end{tabular}

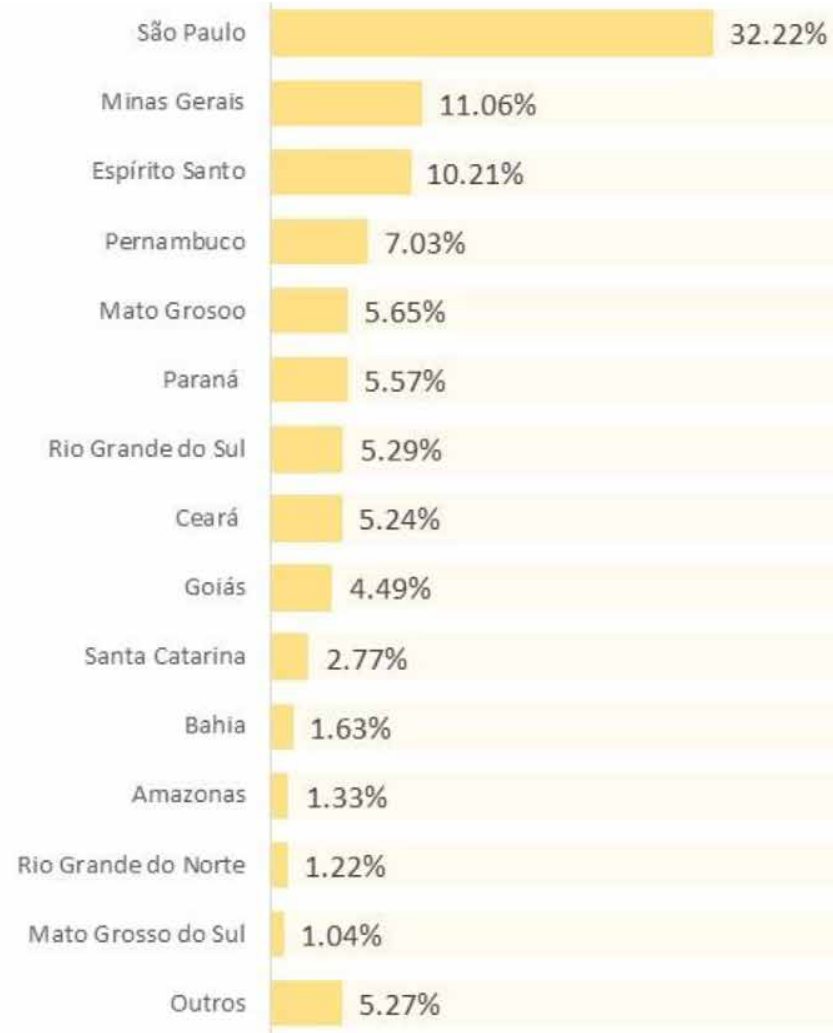

Figure 6. Share of chick housing by state, 2018 (IBGE, 2019).

As shown in Figure 7, the increasing demand led farmers in Brazil to respond by increasing production. The Brazilian Association of Animal Protein (ABPA) and the Brazilian Association of Meat Exporters (ABIEC) lauded the increase of egg production in Brazil in 2017 and expect steady growth in the coming years.

According to Table 4, Brazilian egg production increased by 52.1\% from 2007 to 2017. Most of the growth can be attributed to the adoption of new technology by producers, genetic improvement, better sanitation, and advances in bird nutrition. Brazil reached 153.3 million layers in 2017. The country has also faced significant growth in nontraditional egg-producing regions. The center-west region increased production by $112.3 \%$ from 2007 to 2017 . The north and northeast regions registered 25.6 and $65.1 \%$ growth, respectively, during the same period. Despite the low levels of egg production in the northern part of Brazil, production may increase if producers take advantage of the river transportation system (Moura et al., 2019). 


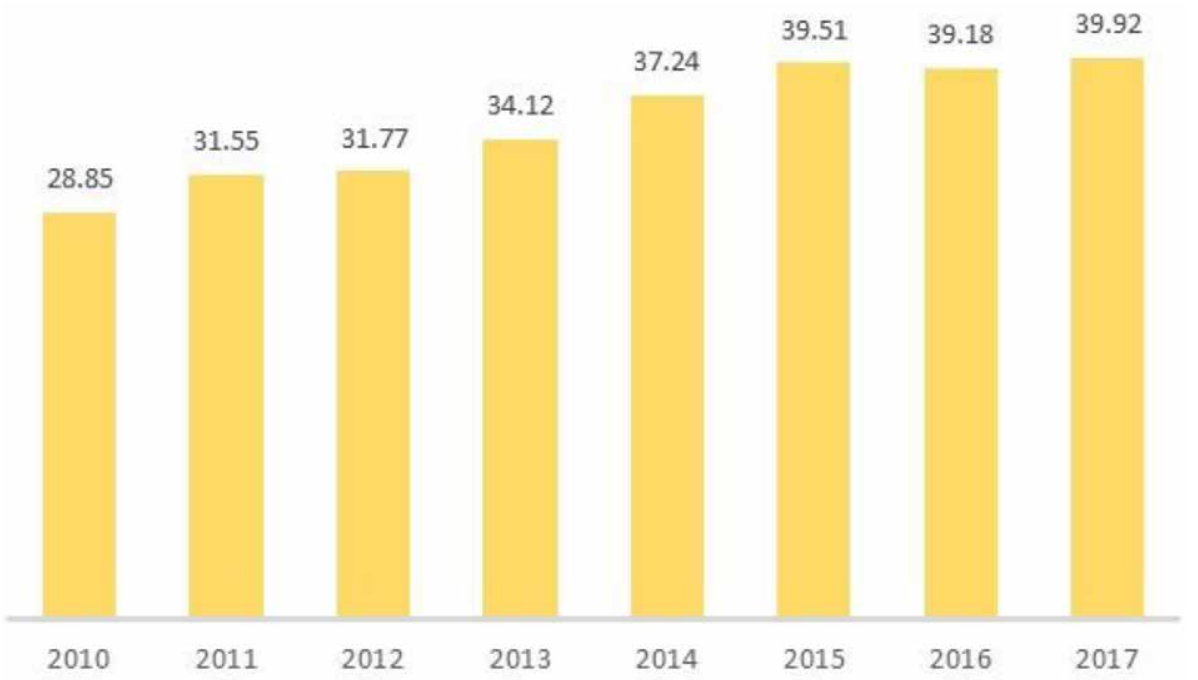

Figure 7. Brazilian egg production by millions of eggs (IBGE, 2019).

Table 4. Brazilian egg production in millions of dozens, by region, 2007-2017 (Moura et al., 2019).

\begin{tabular}{|c|c|c|c|c|c|c|}
\hline Year & North & Center-West & Northeast & South & Southeast & Total \\
\hline 2007 & 62,369 & 196,897 & 290,060 & 495,985 & $1,118,264$ & $2,163,575$ \\
\hline 2008 & 66,241 & 212,714 & 306,820 & 525,175 & $1,166,823$ & $2,277,773$ \\
\hline 2009 & 79,002 & 244,172 & 323,018 & 530,969 & $1,179,855$ & $2,357,016$ \\
\hline 2010 & 65,231 & 291,309 & 331,191 & 549,364 & $1,216,506$ & $2,453,601$ \\
\hline 2011 & 59,954 & 331,361 & 351,847 & 601,903 & $1,217,337$ & $2,562,402$ \\
\hline 2012 & 67,906 & 362,092 & 371,203 & 613,640 & $1,280,638$ & $2,695,479$ \\
\hline 2013 & 71,134 & 379,073 & 373,948 & 603,485 & $1,312,682$ & $2,740,322$ \\
\hline 2014 & 69,962 & 373,746 & 384,886 & 617,192 & $1,379,092$ & $2,824,878$ \\
\hline 2015 & 74,154 & 375,986 & 401,516 & 669,762 & $1,405,924$ & $2,927,342$ \\
\hline 2016 & 74,739 & 400,315 & 442,437 & 680,338 & $1,488,087$ & $3,085,916$ \\
\hline 2017 & 78,345 & 417,967 & 478,791 & 719,340 & $1,596,200$ & $3,285,509$ \\
\hline Growth 2007-2017 (\%) & 25.62 & 112.28 & 65.07 & 45.03 & 42.74 & 52.09 \\
\hline
\end{tabular}

The fast increase of supply in response to demand shocks led to stability in the egg prices until 2017. During 2017, the price of eggs in Brazil mostly followed the inflation rate. But from January 2018 to September 2018, egg prices in Brazil decreased by 1.75\%, placing them far below the inflation rate of the period, which was around 3.3\% (IBGE, 2019). During this time, a low unit price made eggs a good protein option for low-income consumers, and the sales volume increased.

Using data from Q3 2018, IBGE (2019) showed that 1,042 farms (55.6\% of total egg-producing farms in Brazil) produced table eggs, while 833 (44.4\% of total) farms produced hatching eggs. During the same quarter, Brazil produced 919.5 million dozen ${ }^{2}$ eggs, an increase of almost $5 \%$ in relation to the previous quarter and a 9\% increase over Q3 2017. Table eggs represented almost 80\% of the total egg production in Brazil, and hatching eggs were a little more than $20 \%$ of total production. Figure 8 shows the evolution of egg production in Brazil by quarters. The steady increase in egg production resulted in Q3 2018 being the largest egg-producing quarter of the historical series, which began in 1987.

\footnotetext{
230.65 million boxes
} 
The growth of more than 75.7 million dozen eggs between the Q3 2017 to Q3 2018 can be explained by an increase of egg production in 23 out of the 26 Brazilian states. The state of São Paulo increased production by 24.74 million dozen ( 825,000 boxes of 30 dozen) and the increase in Espírito Santo was almost 14.3 million dozen (476,000 boxes of 30 dozen), making them the Brazilian states with the highest increase during the period.

International trade does not account for a significant part of the egg market. Imports are insignificant, representing less than $1 \%$ of the market. The internal market supplies and consumes most of the eggs produced, as shown in Figure 9.

The Brazilian internal market for eggs consists of several players. As in other parts of the world, Brazilian producers supply eggs to different sectors of the economy, including retailers, food services, and institutions ${ }^{3}$ as well as to other industries that use eggs as inputs. The retail sector was the largest buyer in 2017, particularly supermarkets and hypermarkets. They tend to carry the largest variety of eggs - white, brown, and organic - which tends to be convenient for consumers.

However, per capita consumption in Brazil remains relatively low if compared to other countries, as indicated in Table 2. For instance, a consumer in the United States consumed on average more than 280 eggs per year in 2018 (United Egg Producers, 2019), while Brazilians consumed an average of 212 eggs per capita that same year, as seen in Figure 10. The potential for higher egg consumption in Brazil, a middle-income nation, comes from the low cost-benefit ratio of eggs among animal protein products - both in economic terms (cost per serving) and in nutrition (grams of protein per dollar spent), as seen in Table 5. In fact, the data from 2010 to 2018, depicted in Figure 10, shows the growth rate in egg consumption in Brazil is trending higher than in the United States: $42 \%$ in the former compared to $12 \%$ in the latter (Table 2). Coupled with the information that income has increased in Brazil during the period, the increase in egg consumption suggests that Brazil has a high-income elasticity of demand for eggs, which implies that further favorable income shocks can greatly increase Brazilian egg consumption.

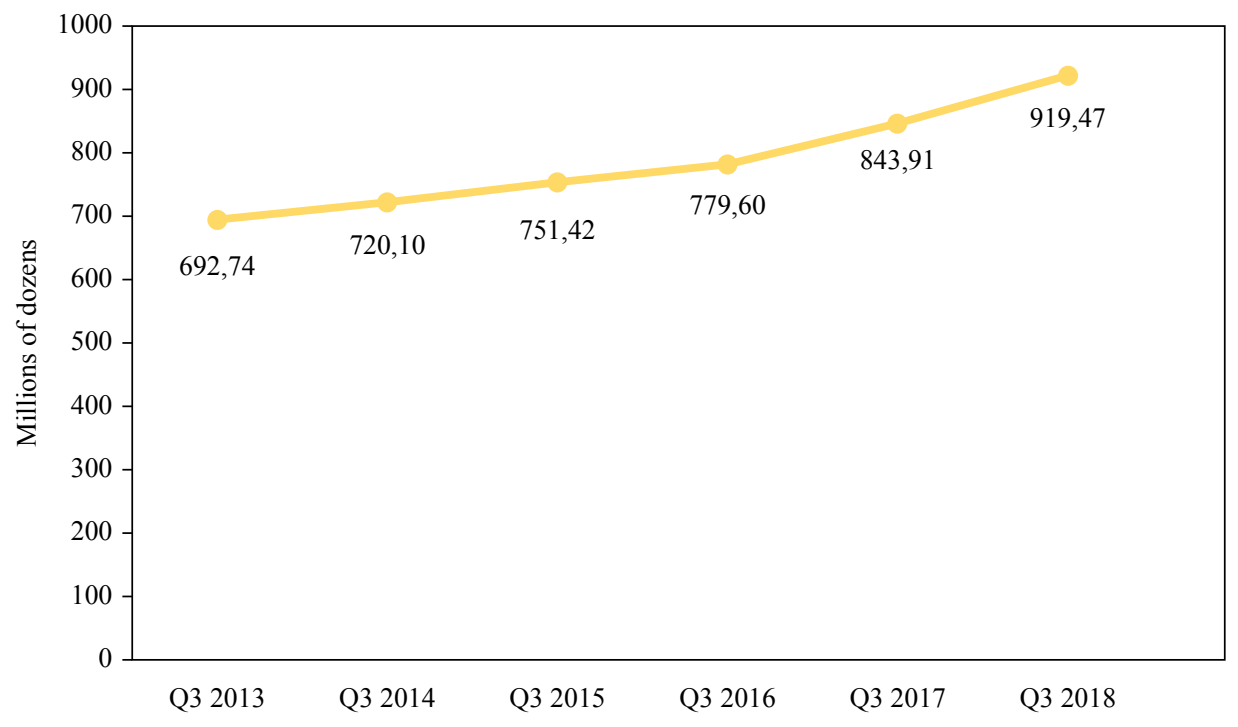

Figure 8. Brazilian egg production, Q1 2013 to Q3 2018.

\footnotetext{
${ }^{3}$ For example, hotels, restaurants, schools, and hospitals.
} 
Internal Market

$99.74 \%$

Figure 9. Destination of Brazilian egg products in 2017.

\section{The competitive environment of the Brazilian egg market}

Mantiqueira is currently the biggest egg producer in Brazil and South America and the second largest in Latin America, and it ranks $12^{\text {th }}$ in the world, as seen in Figure 11. But despite its size, Mantiqueira only has a 5\% share in the fragmented Brazilian egg market. Thus, competition is intense, not only between large producers but also between small producers. For instance, it is not uncommon to see small retailers using Volkswagen Buses to sell eggs in bulk across multiple locations in Brazilian cities.

But the company aims to leverage its production capacity. Mantiqueira sells in every formal market in Brazil: in bulk, in packages, and in the market of eggs with differentiated attributes. Using the slogan 'Eggs also have a brand; buy Mantiqueira eggs,' the company's strategy is to imprint the Mantiqueira brand into consumers' minds.

Branding has been a strategy used not only in the Brazilian egg market but also worldwide. To stand out in a competitive market, Mantiqueira seeks to establish an effective bond with consumers, using the idea of

Table 5. Average retail cost of high-quality protein product - January 2019 (American Egg Board, 2019).

\begin{tabular}{|c|c|c|c|c|c|c|}
\hline Protein Food & Avg. cost & $\begin{array}{l}\text { Serving } \\
\text { size }\end{array}$ & $\begin{array}{l}\text { Cost per } \\
\text { serving }\end{array}$ & $\begin{array}{l}\text { Calories } \\
\text { per serving } \\
\text { (kcal) }\end{array}$ & $\begin{array}{l}\text { Protein per } \\
\text { serving (g) }\end{array}$ & $\begin{array}{l}\text { Grams of protein } \\
\text { per dollar } \\
\text { serving }(g / \$)\end{array}$ \\
\hline Eggs, grade A large & $1.60 / \mathrm{doz}$ & $1 \mathrm{egg}$ & 0.13 & 72 & 6 & 46 \\
\hline Milk, reduced fat, $2 \%$ milkfat & 2.88/gal. & $8 \mathrm{oz}$ & 0.18 & 122 & 8 & 44 \\
\hline $\begin{array}{l}\text { Chicken breast, skinless, } \\
\text { boneless }\end{array}$ & 3.05/lb. & $3 \mathrm{oz}$. & 0.57 & 102 & 19 & 33 \\
\hline Ground beef, $90 \%$ lean meat & $5.25 / \mathrm{lb}$ & $3 \mathrm{oz}$. & 0.98 & 149 & 17 & 17 \\
\hline Pork chops, boneless & $3.73 / 1 \mathrm{~b}$ & $3 \mathrm{oz}$. & 0.70 & 132 & 18 & 26 \\
\hline $\begin{array}{l}\text { Beef, round roast, } \\
\text { USDA choice, boneless }\end{array}$ & $4.81 / 1 \mathrm{~b}$. & 4.8/lb. & 0.90 & 147 & 19 & 20 \\
\hline
\end{tabular}

emotional branding to retain buyers. 


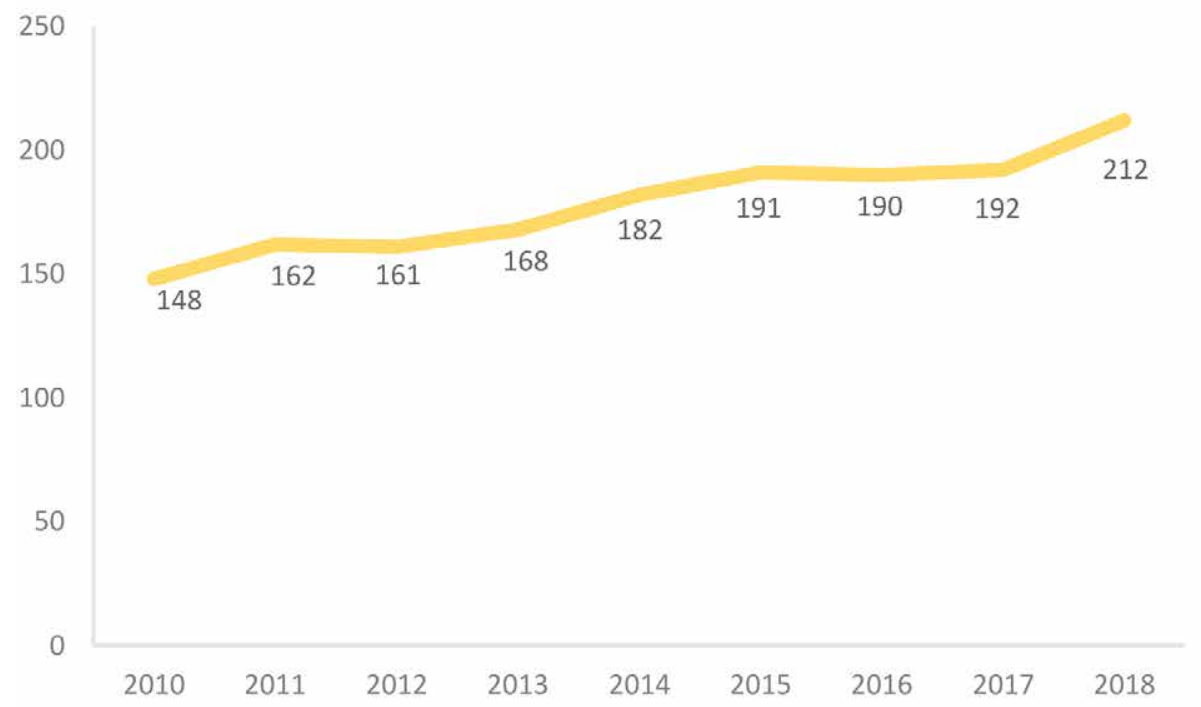

Figure 10. Evolution of per capita egg consumption in Brazil (ABPA, 2018).

\begin{tabular}{|c|c|c|c|}
\hline Rank & Company & Country & $\begin{array}{c}\text { Layers } \\
\text { (million head) }\end{array}$ \\
\hline 1 & $\begin{array}{l}\text { Cal-Maine Foods (including } \\
\text { Hillandale Farms) }\end{array}$ & United States & 40.1 \\
\hline 2 & Proteina Animal (PROAN) & Mexico & 33 \\
\hline 3 & Rose Acre Farms & United States & 26.9 \\
\hline 4 & $\begin{array}{l}\text { CP Group (worldwide } \\
\text { operations of CP Foods) }\end{array}$ & Thailand & 22 \\
\hline 5 & Ise Inc. & Japan & 20 \\
\hline 6 & Versova Holdings LLC & United States & 16.4 \\
\hline 7 & $\begin{array}{l}\text { Arab Company for livestock } \\
\text { Development (ACOLID) }\end{array}$ & Saudi Arabia & 13.4 \\
\hline 8 & Daybreak Foods & United States & 13 \\
\hline 9 & Kazi Farms Group & Bangladesh & 12.7 \\
\hline 10 & Rembrandt Enterprises & United States & 12.5 \\
\hline 11 & Michael Foods & United States & 12.2 \\
\hline 12 & Granja Mantiqueira & Brazil & 12 \\
\hline 13 & $\begin{array}{l}\text { CP Foods (including Chia } \\
\text { Tai Group, COFCO) }\end{array}$ & Thailand & 12 \\
\hline 14 & Avangardco & Ukraine & 10.7 \\
\hline 15 & Avril Group & France & 10 \\
\hline 16 & El Calvario & Mexico & 10 \\
\hline 17 & Empresas Guadalupe & Mexico & 10 \\
\hline 18 & Granja Yabuta & Brazil & 10 \\
\hline 19 & Wadi Group & Egypt & 10 \\
\hline 20 & Center Fresh Group & United States & 9.7 \\
\hline
\end{tabular}

Copyright WATT Global Media 2018

Figure 11. Top egg producers in the world, 2018 data (WATTAgNet, 2018).

With emotional branding, scholars argue that consumer fidelity does not arise from marketing the tangible or symbolic benefits of the product, even if those benefits boost self-esteem or consumers' status (Holt, 2006). Rather, the bond between consumers and brand can be strengthened under narratives that appeal to empathy or situations that connect to consumers' dreams and aspirations, their life story, and the brand itself.

As a brand, Mantiqueira had already established roots in the first market it entered: Rio de Janeiro. There, $96 \%$ of the consumers state they are 'very satisfied/satisfied' with Mantiqueira eggs, $87 \%$ say these are 'the best eggs,' and 97\% affirm that they 'will keep buying' Mantiqueira products, according to internal research. 
Despite its strong presence in Rio, the company has a weaker presence in other Brazilian cities. Thus, to reach different segments of the market and strengthen its brand, Mantiqueira launched differentiated packaging for its products to highlight their various attributes.

\subsection{Communication campaigns}

In another effort of branding, Mantiqueira personalized its eggs with a heart-shaped stamp that says: 'You can always trust those with heart.', as shown in Figure 12 and 13.

\subsection{New products}

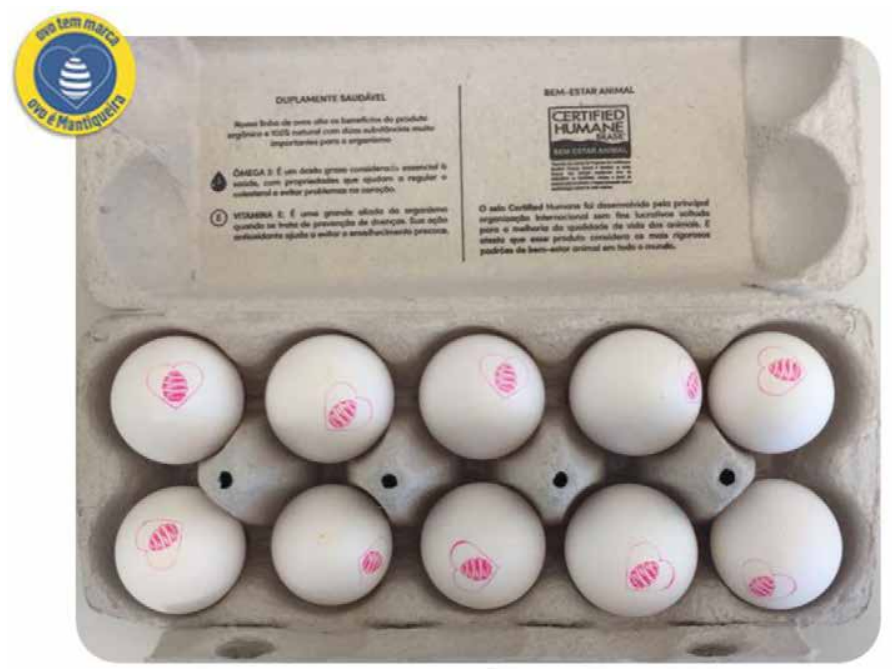

Figure 12. Mantiqueira stamped eggs.

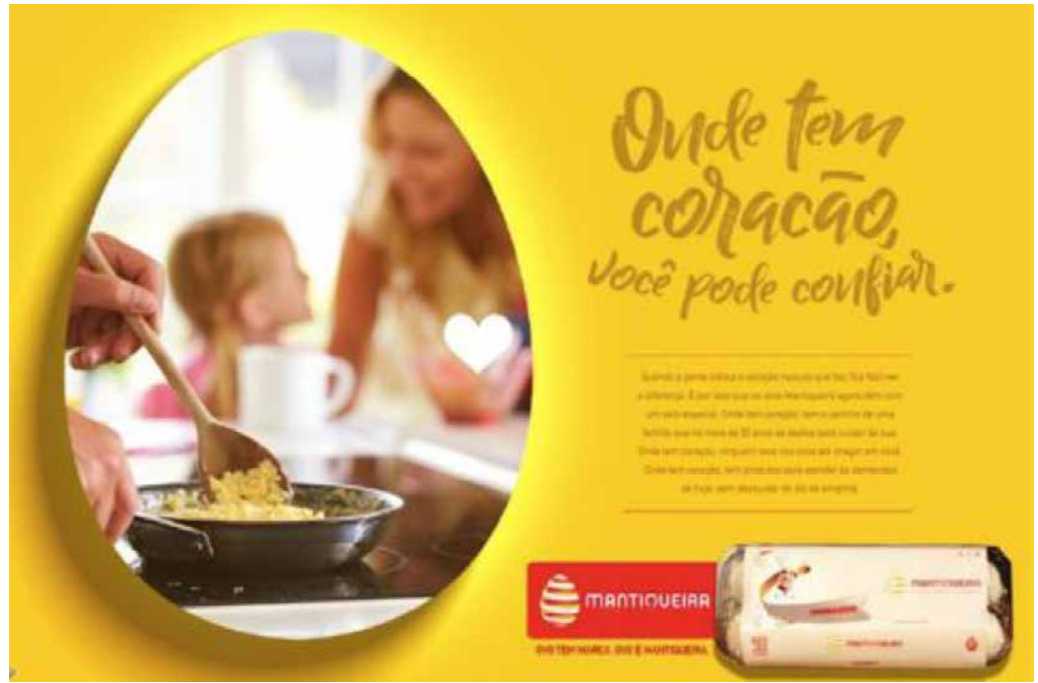

Figure 13. Mantiqueira advertisement - the figure reads: 'You can always trust those with heart.'

Following global tendencies, Mantiqueira launched two new products/services in 2019. The first, named the Egg Club, is structured in a similar fashion as meal delivery kits. Figure 14 shows part of an advertisement campaign for the Egg Club. Members of the club select the type of eggs they would like to purchase and the frequency of deliveries to their homes. The company believes that this convenient channel will connect the 
client to the company by personalizing the consumer's shopping experience. This strategy may help boost the egg producer's share of the final retail price above the current $40 \%$ depending on the total cost of the system (digital platforms, delivery, and other costs).

The second product is aimed at a different market segment: vegan consumers. According to the Brazilian Vegan Society, the market of vegan products grows around $40 \%$ each year in Brazil. Mantiqueira entered the vegan market with a plant-based, vegan-friendly substitute for its main product, the egg. Named 'N.ovo'4, the product is designed to mimic the taste, texture, and structure that eggs would give to cakes, pasta, and pancakes.

N.ovo comes in a box similar to conventional eggs, as shown in Figure 15, even though it is actually a powdered product. A measuring cup is included inside every N.ovo package.

\section{Trends in the egg market}

According to the Brazilian Bank of Development (BNDES), consumption of eggs can be greatly increased by taking advantage of industrialized eggs (BNDES, 2016), known in the industry as egg products. The BNDES conclusion is supported by a worldwide trend: egg products took $25 \%$ of the egg market in the European Union, $30 \%$ in the United States, and $49 \%$ in Japan. Moreover, egg products can be targeted to both the final consumer and processors.

Egg products can be either liquid or dehydrated (powdered). Many contain only the egg white or the egg yolk. To be considered an egg product, eggs must represent more than half of the mixture when combined with other ingredients (e.g. salt, sugar, enzymes).

Egg products were developed to make better use of products that were deemed unsuitable as table eggs for the final consumer, such as damaged or low-quality eggs. But because egg products have a longer shelf life, their prices are more stable over time as compared to shell eggs, effectively making egg products a consistent stream of revenue for companies (BNDES, 2016).

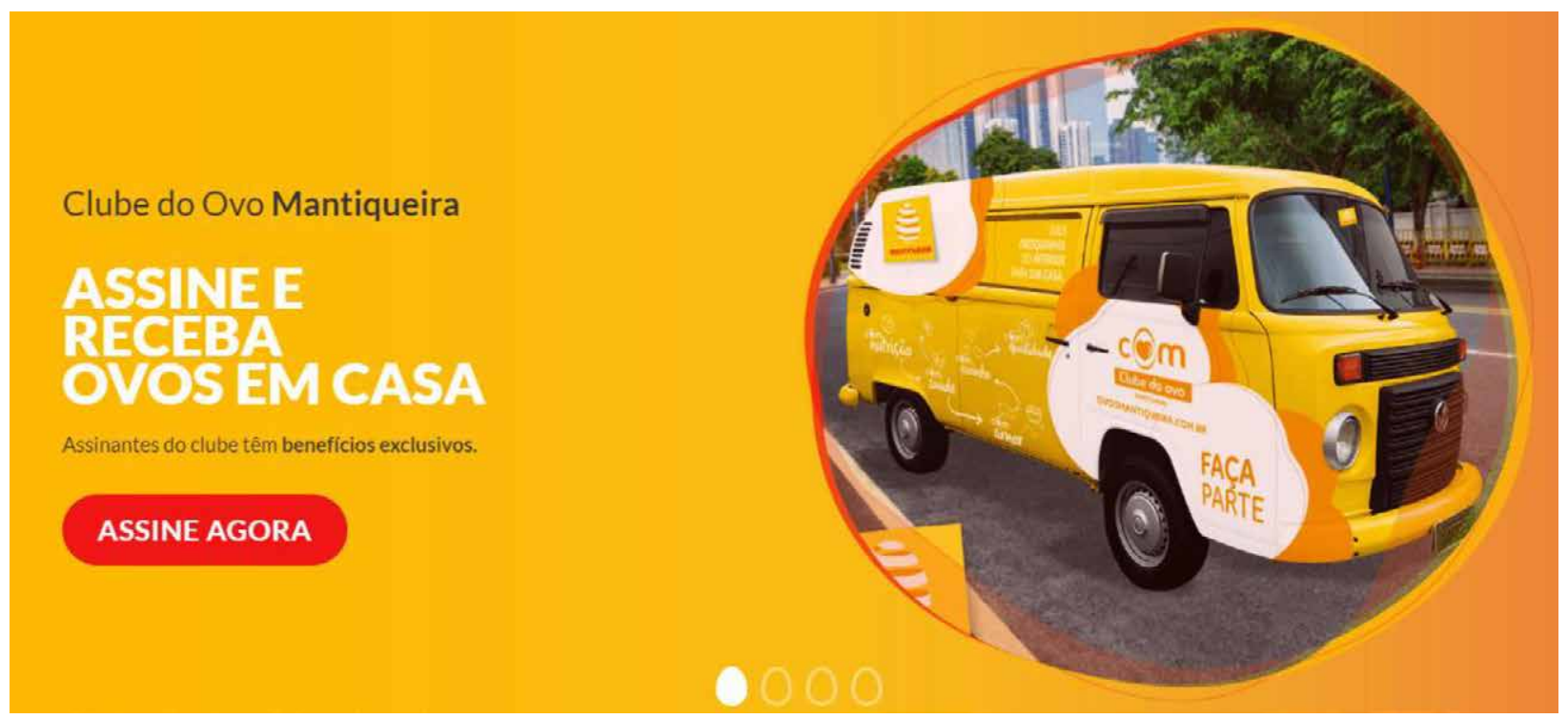

Figure 14. Egg Club campaign - the figure reads: 'Sign up and receive eggs at home.' (Mantiqueira, 2019).

\footnotetext{
${ }^{4}$ In Portuguese, 'Novo' means new and 'ovo' means egg. The product's name, N.ovo, combines these two words.
} 


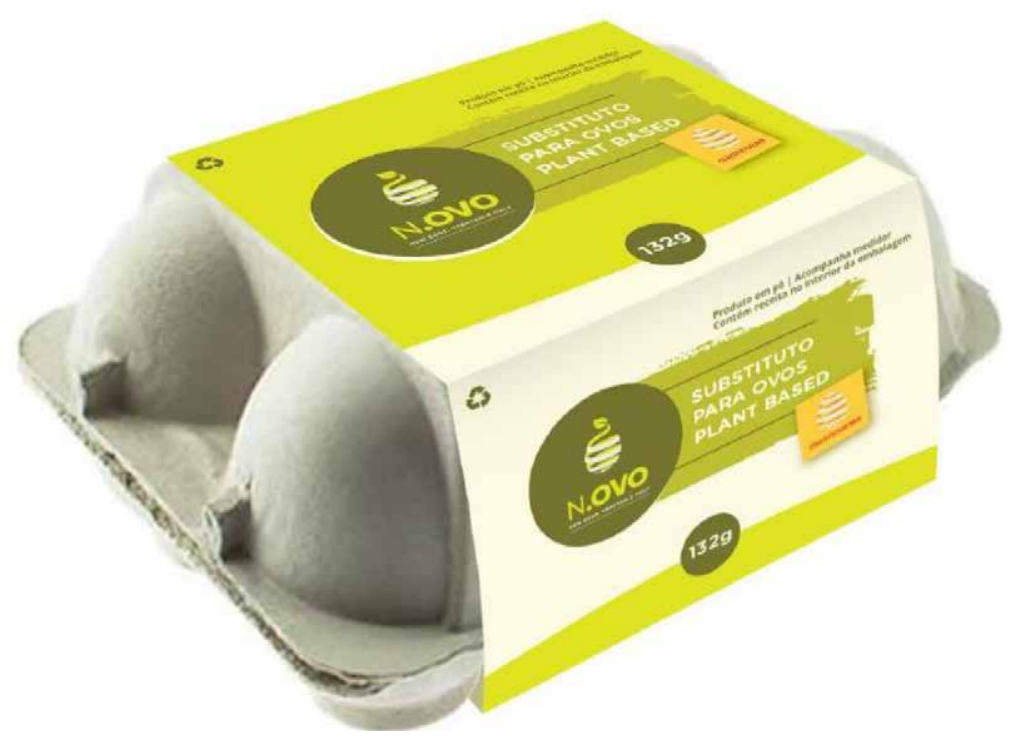

Figure 15. N.ovo package.

From the consumer's point of view, egg products have become a convenient alternative. They allow for simpler handling, longer storage, better transportation - as eggs in the shell can break - and higher levels of food security since contamination tends to decrease after processing (Kakimoto, 2011). For instance, according to BNDES (2016) guidelines recommend that liquid eggs be consumed, on average, within four weeks if stored without refrigeration or within 10 weeks if refrigerated. Some products in the market claim to last up to 75 days before spoilage. Depending on who the final consumer is, liquid eggs are packaged in bags, tank trucks with cooling systems, or in Tetra Pak ${ }^{\circledR}$-style carts.

Ready-to-eat eggs also have gained traction among consumers. For instance, hard-boiled eggs, egg-based tortillas, scrambled eggs in bags, and ready-to-eat egg-based products with an expiration date up to seven weeks in the future can be found in current markets.

Dehydrated eggs (powdered) do not require refrigeration and have a longer expiration period than 'shell' eggs. And dehydrated eggs can be an alternative for consumers who need precise amounts of eggs for their recipes since powdered measurements can often be more precise.

The BNDES (2016) study argues that egg product consumption will increase at the same rate as shell eggs in Brazil, following the trend of the developing world. However, the growth rate of egg products can be divided between the increase in consumption of already existing products and the introduction of new products. As an example, companies recently introduced eggs in spray - used mainly in egg-based recipes - and pre-boiled eggs for individual consumption.

Egg products may increase penetration of Brazilian eggs around the world, as transportation and spoilage become less of a problem. An increase in international trade allows countries to expand popular brand recognition beyond national borders.

Another advantage of consumption of egg products is the capacity of the industry to use egg sub-products. The largest sub-product of industrial egg usage, eggshells, can be inputs to fertilizers because they are rich in calcium, or used in animal feed for the same reason.

The main trend in consumption and production of eggs relates to animal welfare, with examples of governments that have enacted policies that restrict conventional practices and consumers have been willing to pay higher prices for eggs produced under strict animal welfare practices (Mullally and Lusk, 2017; Ochs et al., 2018). 
The European Union, for instance, has already introduced specific directives regarding the welfare of laying hens, and the bloc has been actively discussing animal welfare standards (EFSA, 2019; EU, 1999). California, in 2015, passed animal welfare laws that allowed laying hens to fully turn around and extend their wings (Mullally and Lusk, 2017). Chicken well-being poses a challenge to conventional forms of egg production as consumers have shown a desire to consume cage-free eggs. Led by demand, traditional production methods in developed countries are being adjusted to include alternative production methods, too. Producers have increased the use of enriched cages, cage-free, and free-range systems of production.

Under the conventional system, the size of a cage varies from $350 \mathrm{~cm}^{2}$ to $450 \mathrm{~cm}^{2}$ per hen, allowing an overlay of up to seven cages. According to BNDES (2016), conventional cages are easier to handle and tend to show a lower cost of production. Technology is fully adapted to the conventional system of laying. Conventional cages have fenced-angled floors, which allow eggs to roll down into a transportation tube or belt and out of the barn. Manure falls into collecting conveyor systems, allowing for cleaner eggs and less use of labor.

In a cage-free system, birds freely move inside a barn. Benefits to birds include more natural movements and socialization between hens. Birds are required to have a minimum length of perch space and shared nests for laying. Despite efforts to mechanize the collection of eggs under cage-free systems, handling chickens in this environment requires more labor. Other disadvantages of the cage-free system include negative impact in hen's health and stress, increase morbidity, impacts on hen's behavior (e.g. cannibalization), and feed wastage (see Ochs et al. (2018) for a discussion).

Organic products also gained attraction with consumers that tend to perceive them as healthier and higher quality (Dahlhausen et al., 2018; Lee et al., 2013). Organic production requires that birds feed comes strictly from organic grains but other than that, organic production and conventional production of eggs can be very similar in terms of handling. The guidelines and standards used in Brazilian organic production follow Norm 17/2014 from the Brazilian Department of Agriculture (MAPA).

The Brazilian legislation recognizes other forms of production, identified with the traditional way of handling egg production in rural Brazil. One of them is named the colonial system of production. Under the colonial system, rustic chicken breeds are adapted into conventional production practices: birds are free to pasture in no less than $3 \mathrm{~m}^{2}$ per hen, and feed comes exclusively from plant sources, with synthetic feed inputs and any sort of growth agents forbidden. Certification and enforcement of the colonial practices have been the biggest challenge under this method of production (BNDES, 2016).

A slightly different version of the colonial system is used by smallholders in rural Brazil. The 'caipira' eggs, as they are known, are produced under free-range and pasture- or corn-fed only. They are associated with an unsophisticated production process but praised by consumers for their taste.

Trends in egg production show a clear direction toward cage-free and free-range systems, with a lower density of birds in poultry farms. Figure 16 shows that many countries have diversified their egg production system. Both consumers and governments have indicated a desire for more strict animal welfare standards in the industry - a pattern shown both in the buyers' consumption behavior and in government legislation (EFSA, 2019; WATTAgNet, 2019).

Companies wishing to diversify started to offer products made exclusively from cage-free eggs. Some announced that only cage-free eggs will be in their products by 2025 (WATTAgNet, 2019). It became important for these processors to find suppliers who were using cage-free systems or conversely demand that traditional farmers convert their conventional systems to cage-free. BNDES (2016) believes that organic and enriched eggs ${ }^{5}$ will remain as market niches in Brazil, as their growth rate has not been comparable to that of cage-free eggs.

${ }^{5}$ Eggs are enriched with vitamins, B complex, Omega 3, among others. More information at BNDES (2016). 
However, the market of cage-free eggs is not free from uncertainty. Commitments by processors to buy only cage-free eggs aren't necessarily accompanied by effective plans on how fast they will replace conventional eggs in their products. For instance, in a survey with egg producers, $47 \%$ of them stated that their clients have made future commitments to convert to $100 \%$-cage-free eggs, but only $12 \%$ have established interim benchmarks on how to achieve that goal (WATTAgNet, 2019).

Mantiqueira became the first company to produce cage-free eggs in Brazil. Approximately 500,000 hens owned by the company produce eggs certified by the seal Certified Humane Brasil following the international standards known as Certified Humane Raised \& Handled.

Uncertainty can also arise from the pace of innovation for food products as the food sector tries to keep up with shifts in consumer preferences. Market specialists argue that cage-free eggs can already be obsolete in the agenda of food sustainability as proponents of the 'food movement' tend to argue against animalprotein diets. In their view, plant-based diets could reduce the environmental damage associated with animal production and improve consumer health outcomes (Saviani, 2019).

The World Resource Institute (WRI) and Princeton University estimated that animal-based protein tends to emit more greenhouse gases (GHG) per gram of protein than other sources, such as plants, as shown in Figure 17. They also showed that the average person consumes more protein than the daily requirement (World Resources Institute, 2019). There seems to be increasing agreement between scholars, environmental agencies, and NGOs about the high environmental cost of animal protein production to the extent that the message has been incorporated by a niche of consumers (Saviani, 2019).

For example, in 2011 Pat Brown, a biochemist and geneticist by training, founded Impossible Burger, a startup company that produces a meat-free burger that mimics the texture and taste of meat. The company is valued at approximately $\$ 2$ billion as of May 2019. The success of Impossible Burger testifies to the power of the vegetarian segment in the protein market. In fact, plant-based burgers are offered in restaurants across

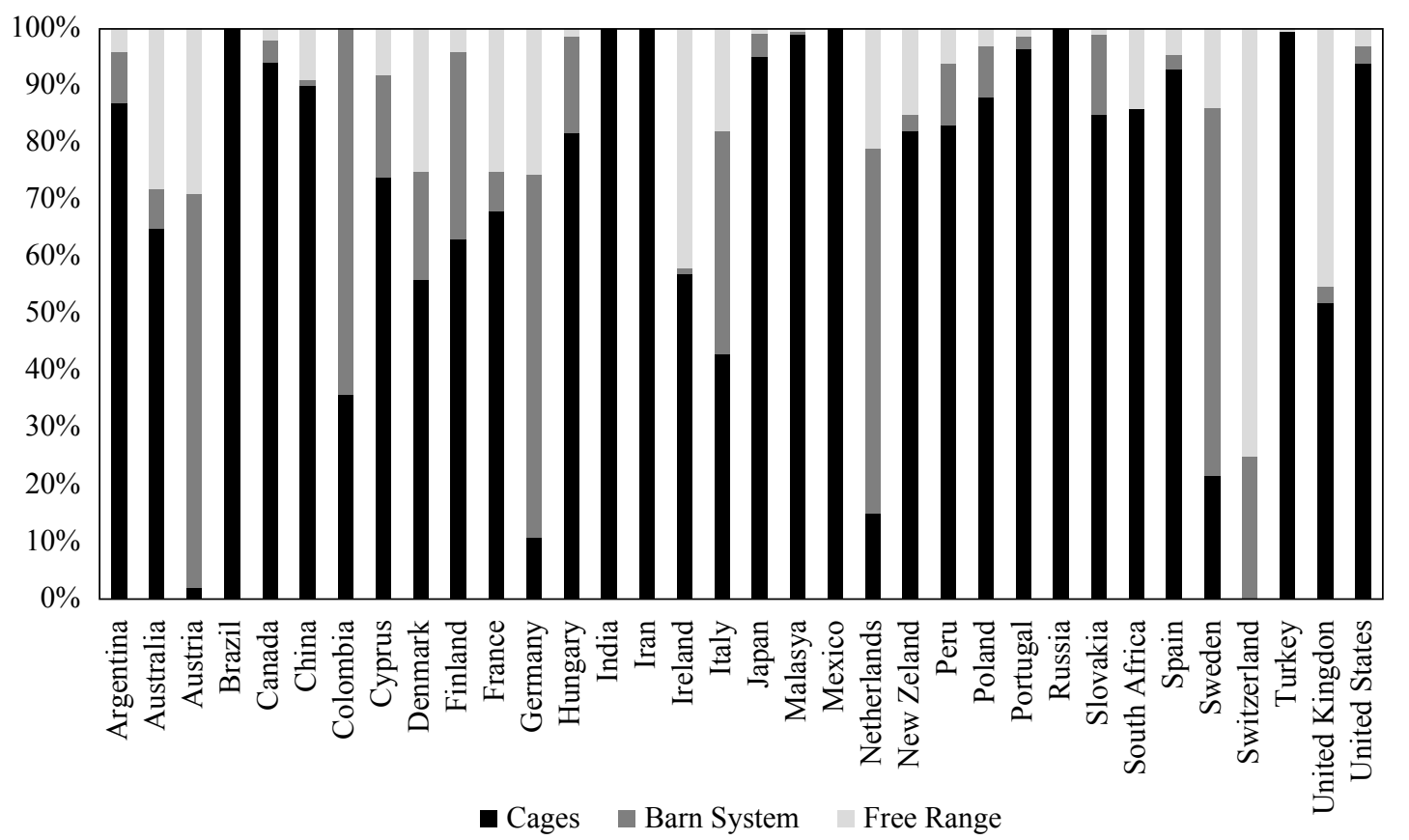

Figure 16. Egg production system by country (IEC, 2015). 
the United States and Impossible Burger has captured millions of dollars in investments, being backed by high-profile investors, such as Bill Gates (Valor Econômico, 2019).

The data in Table 6 shows that the United States had $\$ 3.7$ billion in sales of plant-based products in 2018, while Figure 18 shows the increases in these sales by region from August 2017 to August 2018.

A survey conducted by Mattson Consulting, a strategic marketing company, asked 1,163 consumers about their food habits, behaviors, and beliefs in order to better understand their attitudes toward plant-based protein (Mattson Consulting, 2019). The survey showed that these consumers chose to buy plant-based products

WORLD RESOURCES INSTITUTE

\section{PROTEIN SCORECARD}

What you put on your plate has a large impact on the environment. Research by WRI and its partners shows that meat and dairy are generally more resource-intensive to produce than plant-based foods, increasing pressure on land, water and the climate. Small dietary shifts-such as switching from beef to pork, or poultry to beans-can significantly reduce agricultural resource use and greenhouse gas (GHG) emissions. Use this scorecard to lower your diet's impacts in a way that works for you.

Read more at wri.org/shiftingdiets Join the conversation \#ShiftingDiets

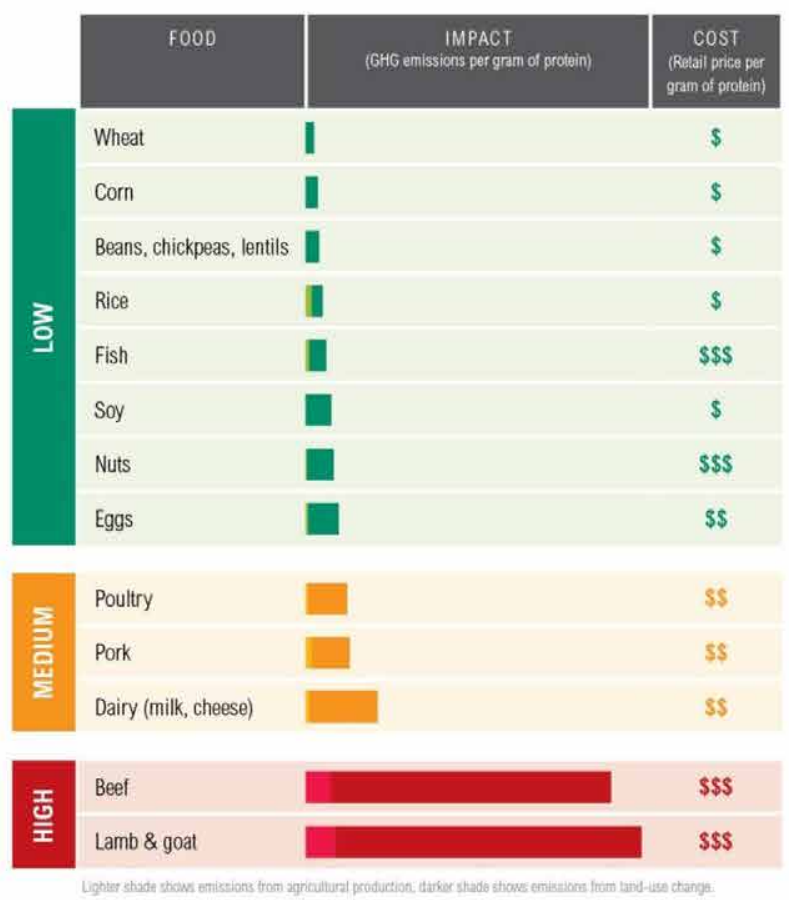

How Much Protein Do You Need?

The average daily adult protein requirement is $56 y$ for a man and $46 \mathrm{~g}$ for a woman but many people consume much more than they need.

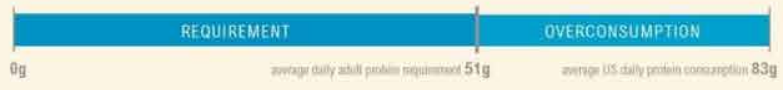

Figure 17. World Resource Institute protein score card (World Resource Institute, 2019). 
for (1) the perceived health benefits; (2) a feeling of well-being from consuming these foods; and (3) for weight loss, as shown in Figure 19.

This trend spills over to plant-based eggs and products that use plant-based substitutes for eggs. Mattson showed that, in 2018, 62\% of retailers in the United States sold 'plant-based eggs and mayo,' with sales reaching more than $\$ 42$ million - an increase of $15 \%$ compared to 2017.

In light of these trends, the future of conventional chicken eggs may be challenging. Companies such as the Norwegian startup EAT aim to convince buyers to reduce egg consumption to two units per week per person by 2050 in order to decrease the environmental impact of animal-sourced proteins (EAT, 2019; Saviani, 2019). But eggs supply important nutrients to humans at a relatively low price. A single egg contains 6 grams of protein as well as vitamin B12, vitamin E, folic acid, calcium, and zinc, among other vitamins

Table 6. Plant-based category sales (\$ million) (The Good Food Institute, 2019).

\begin{tabular}{lrr}
\hline Category & Sales & \$ Sales changes vs YA \\
\hline & & $9 \%$ \\
Plant-based milk & $1,821.9$ & $23 \%$ \\
Plant-based meat & 683.7 & $40 \%$ \\
Plant-based ice cream and frozen novelties & 232.0 & $25 \%$ \\
Plant-based meals & 209.7 & $55 \%$ \\
Plant-based yogurt & 174.1 & $6 \%$ \\
Plant-based butter & 168.8 & $41 \%$ \\
Plant-based cheese & 133.2 & $62 \%$ \\
Plant-based creamer & 124.3 & $9 \%$ \\
Plant-based tempeh & 107.2 & $15 \%$ \\
Plant-based eggs and mayonnaise & 42.4 & $-12 \%$ \\
Plant-based ready-to-drink (RTD) coffee & 34.1 & $29 \%$ \\
Plant-based dressing, sour cream, dips & 12.4 & $17 \%$ \\
Total plant-based products & $3,744.7$ & $9 \%$ \\
\hline
\end{tabular}

${ }^{1} \mathrm{YA}=$ year ago.

Plant-based alternative dollar sales growth by region

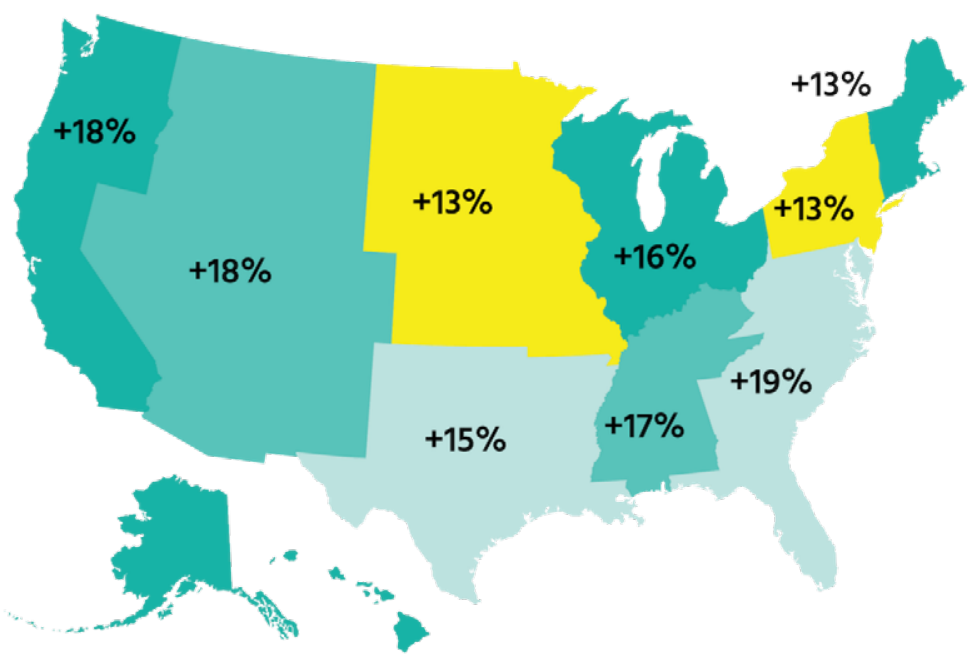

Figure 18. Increases in United States sales of plant-based products by region, August 2017 to August 2018. 


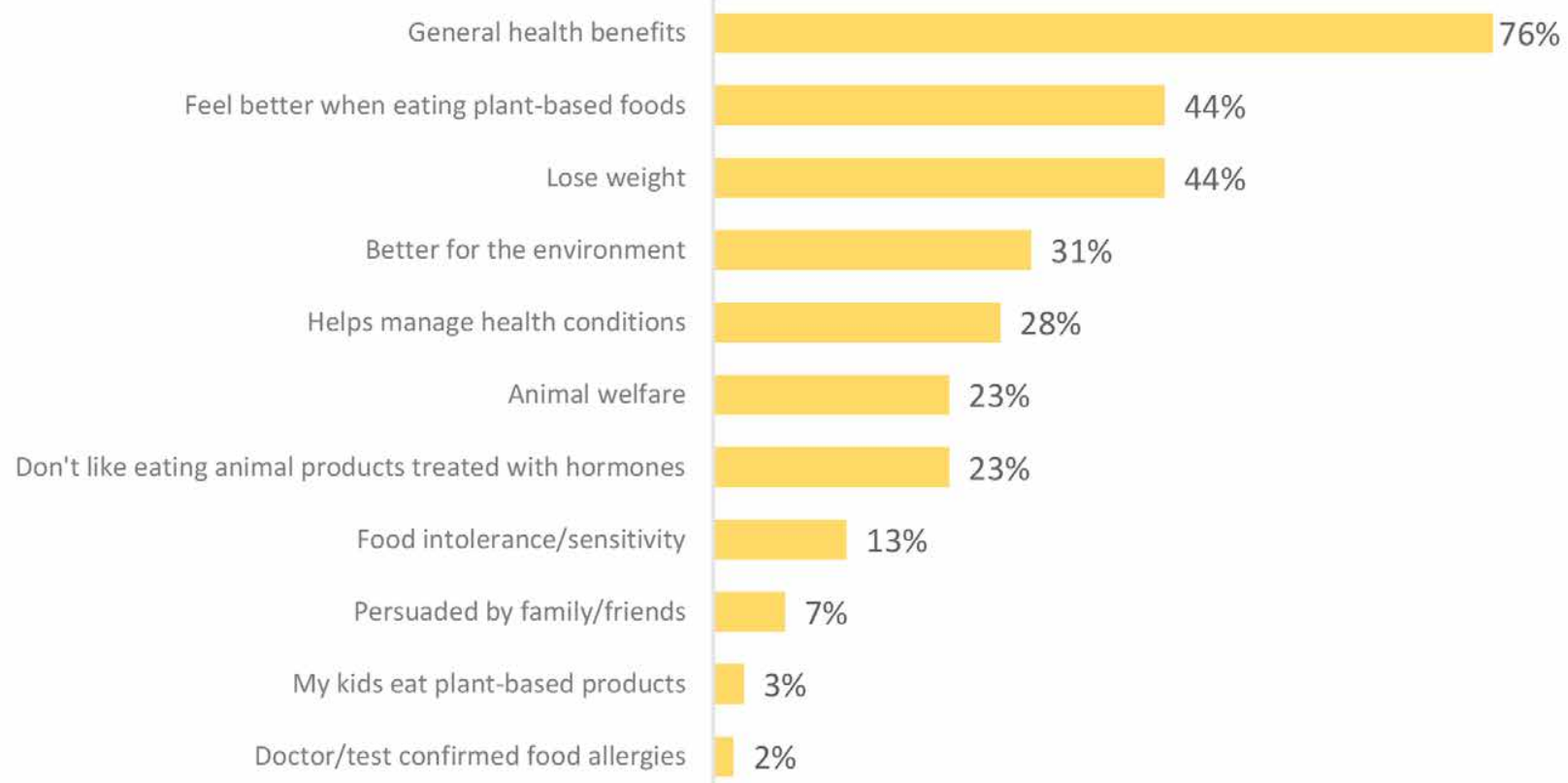

Figure 19. Top reasons consumers reported choosing plant-based foods (Mattson Consulting, 2019).

and minerals. And it can be argued that the environmental impacts of a hen are relatively small compared to its productive capacity. Laying hens produce an average of 300 eggs per year during an average lifespan of two years. When taken together with improvements in the efficiency of animal feeding, such figures make eggs the most efficient animal-sourced protein in the world.

According to a meta-analysis by Clark and Tilman (2017) that uses the information of 742 food production systems of over 90 foods from 164 published life cycle assessments, eggs produce 24.4 grams of $\mathrm{CO}_{2}$ equivalent per gram of protein, which is a little more than rice $\left(21.2 \mathrm{gCO}_{2} \mathrm{e} /\right.$ gram of protein $)$ and below all other animal-based proteins. Eggs use 0.049 square meters of land per gram of protein. In comparison, wheat uses 0.035 square meters per gram of protein, and beef needs 1.04 square meters to produce a gram of protein. Finally, eggs use 29 liters of water per gram of protein. This figure is close to the average plant water use (26 liters/gram of protein) and higher than average water use by grains (21 liters/gram of protein), as reported by Saviani (2019). Clark and Tilman (2017) conclude that eggs have a moderate environmental impact, while plant-based food has a low environmental impact.

\section{Strategic dilemmas}

After the interview, Leandro Pinto is proud of his history leading Mantiqueira. He is aware that new trends in the market will challenge his company and that he will have to make difficult strategic decisions moving forward. But his belief in the power of innovation drives him to new markets and opportunities.

Mr. Pinto has reached a crossroads, but the paths may not be mutually exclusive. He must decide whether to keep branding Mantiqueira and entering new markets and how much to invest in new systems of production, such as cage-free eggs.

\section{Questions:}

1 Consumers still perceive eggs as a commodity. Should Mantiqueira step back and return to a strategy of providing eggs with the smallest average cost, or should the company keep promoting its name and brand to supermarkets and final consumers? 
2 Demand for cage-free products is growing, but it has not yet taken a large share of the market. Thus, Mantiqueira Group sells cage-free eggs with a small profit margin. Should Mr. Pinto keep investing in a caged system of production or move further into the cage-free system?

3 Mantiqueira Group has diversified its product portfolio. What other product lines make sense for Mantiqueira in the future?

4 Given the dynamics of the shifting channels for reaching consumers, what channel strategies might make sense for Mantiqueira in the future?

5 Mantiqueira currently has 2 partners. Would you recommend seeking more partners to provide capital for the company's new growth opportunities? What criteria would you advise management to consider when deciding to invite new investment partners.

6 In your opinion, what are the most important decisions (good and bad) that put Mantiqueira in their current position?

\section{Supplementary material}

Supplementary material can be found online at https://doi.org/10.22434/IFAMR2020.0031

Appendix 1. A culture of sustainability and social responsibility

Figure S1. Mantiqueira's product line.

Figure S2. Animal protein consumption in Brazil, 1986 to 2017.

\section{References}

American Egg Board. 2019. Egg industry overview. American Egg Board, Chicago, IL, USA. Available at: https://www.aeb.org/farmers-and-marketers/industry-overview

Associação Brasileira de Proteína Animal (ABPA). 2018. Relatório anual 2018. ABPA, São Paulo, Brazil.

Banco Nacional de Desenvolvimento (BNDES). 2016. Avicultura de postura: estrutura da cadeia produtiva, panorama do setor no Brasil e no mundo e o apoio do BNDES. BNDES, Rio de Janeiro, Brazil.

Cal-Maine Foods, Inc. 2018. 2018 Annual report. Cal-Maine Foods, Inc., Jackson, MS, USA.

Clark, M. and D. Tilman. 2017. Comparative analysis of environmental impacts of agricultural production systems, agricultural input efficiency, and food choice. Environmental Research Letters 12(6): 064016.

Dahlhausen, J.L., C. Rungie and J. Roosen. 2018. Value of labeling credence attributes - common structures and individual preferences. Agricultural Economics 49(6): 741-751.

EAT. 2019. Who we are. Available at: https://eatforum.org/about/who-we-are/

European Food Safety Authority (EFSA). 2019. Animal welfare. EFSA, Parma, Italy. Available at: https:// www.efsa.europa.eu/en/topics/topic/animal-welfare

European Union (EU). 1999. Council Directive 1999/74/EC. of 19 July 1999 laying down minimum standards for the protection of laying hens. Official Journal of the European Communities L 203: 53-57. Available at: https://tinyurl.com/yy73otbt

Holt, D.B. 2006. Toward a sociology of branding. Journal of Consumer Culture 6(3): 299-302.

Instituto Brasileiro de Geografia e Estatística (IBGE). 2019. Produção de ovos de galinha. IBGE, Rio de Janeiro, Brazil. Available at: https://tinyurl.com/y38dt9bv

International Egg Commission (IEC). 2015. Egg industry review 2015. IEC, London, UK. Available at: http://www.internationalegg.com/wp-content/uploads/2015/08/AnnualReview_2015.pdf

Kakimoto, S.K. 2011. Fatores Críticos da competitividade da cadeia productiva do ovo no estado de São Paulo. MSc-thesis, Universidade Federal de São Carlos, São Carlos, Brazil.

Lee, W.J., M. Shimizu, K.M. Kniffin and B. Wansink. 2013. You taste what you see: do organic labels bias taste perceptions? Food Quality and Preference 29(1): 33-39.

Mantiqueira. 2019. Mantiqueira. Available at: https://www.ovosmantiqueira.com.br/quem-somos

Mattson Consulting. 2019. Meteoric rice in flexitarian eating and how hpp can play a role. Mattson Consulting, Foster City, CA, USA. Available at: https:/universalpure.com/wp-content/uploads/2017/08/2017HPP-Summit-Presentation-BarbStuckeyMain-Mattson.pdf 
Moura, J.B., M.A.A. Feil and S. Sgavioli. 2019. 10 anos de produção e exportação de ovos de poedeiras comerciais no Brasil. A revista do ovo 52.

Mullally, C. and J.L. Lusk. 2017. The impact of farm animal housing restrictions on egg prices, consumer welfare, and production in California. American Journal of Agricultural Economics 100(3): 649-669.

Ochs, D.S., C.A. Wolf, N.J.O. Widmar and C. Bir. 2018. Consumer perceptions of egg-laying hen housing systems. Poultry Science 97(10): 3390-3396.

OvoSite. 2019. Desempenho do ovo, na granja, na $38^{a}$ semana de 2020. Available at: http://www.ovosite. com.br/noticias/index.php?codnoticia $=16431$

Saviani, C.M. 2019. Unreplaceable egg: is there a substitute? Available at: https://www.linkedin.com/pulse/ unreplaceable-egg-substitute-carlos-m-saviani/

Terazono, P.E. and T. Bradshaw. 2019. Ele quer tirar a carne do seu hamburguer. Financial Times. Available at: https:/clippingdotblog.wordpress.com/2019/04/08/ele-quer-tirar-a-carne-do-seu-hamburguer-valor/

The Good Food Institute. 2019. Plant-based meat, eggs, and dairy. State of the industry report. The Good Food Institute, Washington, DC, USA. Available at: https://www.gfi.org/non-cms-pages/splash-sites/ soi-reports/files/SOI-Report-Plant-Based.pdf

United Egg Producers. 2019. Facts and stats. United Egg Producers, Johns Creek, GA, USA. Available at: https://unitedegg.com/facts-stats/

WATTAgNet. 2019. Which are the world's largest egg producers? Available at: https://www.wattagnet.com/ articles/34304-which-are-the-worlds-largest-egg-producers? $\mathrm{v}=$ preview

World Resources Institute. 2019. Protein scorecard. World Resources Institute, Washington, DC, USA. Available at: https://www.wri.org/resources/data-visualizations/protein-scorecard 